\title{
PROSPEKTUS PERUSAHAAN DAN KEPUTUSAN INVESTASI: STUDI EMPIRIS PERUSAHAAN YANG TERDAFTAR DI BURSA EFEK JAKARTA
}

\begin{abstract}
Hadri Kusuma*)
Abstract

This paper reports the result of the empirical investigation on the usefulness of company prospectuses for investment decisions. The invesment decisions are measured in terms of initial returns for the investment decision in the primary stock market, and 15-day mean adjusted returns after Initial public offering for the investment decision in the secondary stock market. The data of the prospectus used are accounting and non-accounting information. Based on the sample of 91 firm-year observations, the result shows that non-accounting information of the prospectus is relevant for the investment decision in the primary stock market. As well, both accounting and non-accounting information is useful for the investment decision in the secondary stock market. Eventhough some ceveats appear in the study and preclude the generalization, the results are robust.
\end{abstract}

Key Words: Underpricing, initial return, mean adjusted return, underwriter, auditor, listing period, standard diviation, company age, percentage of offered stock value, profitibility, financial leverage, solvability, and investment decisions.

\section{PENDAHULUAN}

Initial public offering (IPO) atau penawaran saham perdana merupakan salah satu cara perusahaan mendapatkan dana dari masyarakat. Harga saham saat penawaran merupakan satu indikator keberhasilan tersebut. Ada dua kemungkinan yang terjadi terhadap harga saham setelah penawaran. Harga saham perdana lebih besar dari harga yang terjadi pada saat saham tersebut mulai diperdagangkan. Kondisi harga saham tersebut disebut sebagai overpricing. Sebaliknya harga saham bisa juga mengalami underpricing. Kondisi ini terjadi bila harga saham perdana lebih kecil dari harga yang terjadi pada saat saham tersebut mulai diperdagangkan di pasar sekunder (Firth dan Smith, 1992). Bila underpricing terjadi, maka investor berkesempatan memperoleh abnormal returns berupa initial return positif.

Fenomena underpricing merupakan topik yang menarik pada literatur keuangan.karena harga pasar saham perdana seharusnya menecerminkan semua informasi yang tersedia. Informasi tersebut biasanya dibuat dan disebarkan sebelum penawaran saham perdana dilakukan (Initial public offering, IPO) dalam bentuk prospektus perusahaan. Menurut Trisnawati (1999) informasi prospektus merupakan salah satu sumber informasi utama

*) Staf Pengajar Fakultas Ekonomi Universitas Islam Indonesia, Yogyakarta 
yang digunakan investor untuk memutuskan apakah berinvestasi pada emiten atau tidak di pasar modal.

Dengan menggunakan initial return sebagai proksi dari keputusan pemodal berinvestasi di pasar modal, penelitian terdahulu menunjukkan informasi-informasi yang termuat dalam prospektus baik akuntansi maupun non-akuntansi berhubungan keputusan investasi. Trisnawati (1999), misalnya, menunjukkan umur perusahaan dan Financial leverage merupakan faktorfaktor utama yang berpengaruh terhadap initial return. Nurhidayanti dan Indiantoro (1998) menunjukkan reputasi auditor, penjamin emisi, prosentase saham yang ditahan tidak berasosiasi signifikan. Tapi Nasiman (2000) menunjukkan bahwa reputasi auditor dan reputasi penjamin emisi berasosiasi secara statistik signifikan dan positif dengan initial return.

Penelitian ini bertujuan untuk menguji kegunaan informasi prospektus dalam pembuatan investasi di pasar modal Indonesia. Ketidak konsitennya hasilhasil penelitian sebelumnya merupakan motivasi utama penelitian ini. Di samping itu, penelitian ini memperluas variabel penelitian dengan menambahkan waktu listing sebagai variabel kontrol seperti yang digunakan oleh Philip et. al. (1995). Untuk memenuhi persyaratan underpricing, observasi yang memiliki initial return yang negatif selanjutnya dikeluarkan dari penelitian.

Untuk mencapai tujuan penelitian tersebut, variabel keputusan investasi diukur dengan dua proksi return saham, yaitu initial return (Beatty, 1989; dan Carter et. al., 1998) dan mean adjusted return 15 hari sesudah IPO. (Christy et. al., 1996; dan Nasirwan, 2000). Sebagai variabel independen, variabel informasi akuntansi meliputi profitibilitas, solvabilitas dan financial perusahaan leverage dan variabel non-akuntansi terdiri dari reputasi auditor, reputasi penjamin emisi, umur perusahaan, prosentase saham yang ditawarkan, diviasi standar dan waktu listing.

\section{REVIEW PENELITIAN TERDAHULU}

Fenomena underpricing yang ditandai dengan return saham positif pada pasar saham perdana merupakan gejala yang umum terjadi dalam pasar modal di dunia. Fenomena ini menarik karena berdasarkan hipotesis pasar yang efisien pada bentuk semikuat (Efficient Market Hypothesis, EMH), para investror seharusnya tidak akan mendapatkan "abnormal return" atau keadaan underpricing (Hanafi, 1998) dengan hanya memanfaatkan informasi publik. Menurut Watt dan Zimmerman (1986) pada pasar semikuat (semistrong form) harga pasar saham seharusnya mencerminkan semua informasi yang dipublikasikan oleh perusahaan. Dengan demikian initial return yang positif tidak akan terjadi.

Di samping teori $\mathrm{EMH}$, teori informasi yang asimetrik bisa juga menjelaskan terjadinya initial return positif pada pasar saham perdana. Menurut Baron (1982) initial return positif berhubungan dengan informasi yang dimiliki oleh penjamin emisi. Penjamin emisi memiliki informasi yang lebih banyak dibandingkan dengan emiten Untuk memperkecil resikonya karena kewajiban membeli saham yang tidak laku dalam perjanjian full commitment, 
penjamin emisi bisa memaksa emiten untuk menjual sahamnya dengan harga yang underpriced.

Rock (1986) juga menunjukkan bahwa asimetrik informasi bisa juga terjadi antara kelompok informed investor dan uninformed investor. Karena informed investors memiliki informasi yang cukup tentang perusahaan, uninformed investors akan mengalami kesulitan untuk bersaing. Agar masalah tersebut tidak muncul, maka harga saham penawaran perdana haruslah underpriced.

Teori pasar yang overreaction (overreaction hypothesis) selanjutnya juga bisa menjelaskan terjadinya initial return positif. Teori ini beranggapan harga saham cenderung meningkat karena reaksi yang berlebihan terhadap emisi saham baru, tapi kemudian pasar melakukan koreksi terhadap harga saham tersebut. Akan tetapi Hanafi (1998) yang mencoba menjelaskan fenomena undepricing di pasar modal berdasarkan teori tersebut menyimpulkan bahwa tidak ada hubungan yang signifikan antara initial return dengan after market performance.

Berbeda dengan Hanafi, Sartono dan Yarmanto (1996) menunjukkan harga saham di BEJ telah bereaksi secara tidak wajar dalam menyesuaikan diri terhadap informasi baru, dimana pelaku pasar akan menilai saham terlalu tinggi dalam bereaksi terhadap kabar baik dan sebaliknya. Dari penelitian itu pasar membutuhkan waktu relatif lama minimal 22 hari untuk mencapai keseimbangan. Artinya pada penawaran perdana bila pasar bereaksi positif maka harga akan cenderung meningkat dan koreksi akan terjadi beberapa lama.

Prospektus perusahaan, yang merupakan salah satu sumber informasi yang relevan dan dapat digunakan untuk menilai perusahaan, dimaksudkan untuk menghindari adanya kesenjangan informasi yang terjadi seperti diuraikan sebelumnya. Beberapa peneliti terdahulu telah menguji keterkaitan antara fenomena initial return positif dengan informasi yang tercantum dalam prospektus perusahaan. Tabel 1 meringkas variabel-variabel yang relevan dan berhubungan dengan fenomena initial return positif dari beberapa penelitian terdahulu yang terpilih.

Walaupun tabel 1 menunjukkan ketidakkonsistenan hasil, akan tetapi secara umum dapat disimpulkan bahwa sebagian besar hasil penelitian sebelumnya menunjukkan bahwa informasi non-akuntansi berpengaruh terhadap initial return positif. Hanya sebagian kecil investor saja yang memanfaatkan informasi akuntansi. Hasil ini bisa diartikan bahwa investor menggunakan informasi non-akuntansi sebagai dasar pengambilan keputusan investasi.

\section{PENGEMBANGAN HIPOTESIS}

Fenomena underpricing terjadi apabila initial return saham bertanda positif. Penelitian terdahulu seperti yang dilakukan oleh Beatty 1989, Kim et. al. (1993), Trisnawati (1998) dan Nasirwan (2000) menggunakan intial return sebagai indikator keputusan investasi di pasar saham perdana. Hasil penelitian 
mereka menunjukkan variabel dependen tersebut dipengaruhi oleh beberapa variabel informasi akuntansi dan non-akuntansi (lihat Tabel 1). Untuk menguji apakah informasi yang tercantum dalam prospektus tersebut berpengaruh terhadap initial return, hipotesis nul dan alternatif 1 dirumuskan sebagai berikut:

$H_{01}$ : Reputasi auditor, reputasi penjamin emisi, umur perusahaan, prosentase saham yang ditawarkan, waktu listing, profitabilitas, solvabilitas, Financial leverage dan standar diviasi return perusahaan tidak berpengaruh secara signifikan terhadap initial return.

$\mathrm{H}_{\mathrm{A} 1}$ : Reputasi auditor, reputasi penjamin emisi, umur perusahaan, prosentase saham yang ditawarkan, waktu listing, profitabilitas, solvabilitas, Financial leverage dan standar diviasi return perusahaan berpengaruh secara signifikan terhadap initial return.

Tabel 1

Ringkasan Beberapa Hasil Penelitian Terdahulu

\begin{tabular}{|l|l|}
\hline Peneliti (Tahun) & Variabel yang berpengaruh \\
\hline Balvers et. al. (1988) & Reputasi auditor dan penjamin emisi \\
\hline Guiness (1988) & Standar diviasi return dan indek harga saham \\
\hline Beatty (1989) & $\begin{array}{l}\text { Reputasi auditor, penjamin emisi, prosentase saham yang } \\
\text { ditawaran, umur perusahaan, dan tipe kontrak penjamin emisi. }\end{array}$ \\
\hline Carter dan Manaster (1990) & Reputasi penjamin emisi. \\
\hline Caster dan Dark (1992) & $\begin{array}{l}\text { Reputasi penjamin emisi, prosentase saham yang ditawaran, } \\
\text { umur perusahaan, gross proceed dan satandar diviasi return }\end{array}$ \\
\hline Kim et. al (1993) & Profitibilitas dan financial leverage. \\
\hline Michaelly dan Shaw (1995) & $\begin{array}{l}\text { Reputasi auditor, penjamin emisi, prosentase saham yang } \\
\text { ditawaran, dan variabel industri }\end{array}$ \\
\hline Philip et. al. (1995) & $\begin{array}{l}\text { Total aktiva, umur perusahaan, waktu listing, standar diviasi } \\
\text { return dan prosentase saham yang ditahan pemilik. }\end{array}$ \\
\hline Christy et. al. (1996) & Tidak ada variabel yang siginifikan. \\
\hline Carter et. al (1998) & $\begin{array}{l}\text { Reputasi penjamin emisi, pengukuran penjamin emisi, dan } \\
\text { umur perusahaan. }\end{array}$ \\
\hline Trisnawati (1998) & Umur perusahaan \\
\hline $\begin{array}{l}\text { Nurhidayati \& Indriantoro } \\
\text { (1998) }\end{array}$ & Nilai penawaran saham dan ukuran perusahaan \\
\hline Daljono (2000) & Reputasi penjamin emisi, dan financial leverage. \\
\hline Nasirwan (2000) & Reputasi penjamin emisi. \\
\hline
\end{tabular}

Variabel return 15 hari seteleh IPO juga digunakan pada penelitian terdahulu. Variabel tersebut mengukur keputusan investasi di pasar saham sekunder. Christy et. al. (1996) menunjukkan bahwa reputasi penjamin emisi dan kompetisi sesama underwriter berpengaruh secara signifikan terhadap return 15 hari sesudah IPO. Nasirwan (2000) juga menyediakan bukti empiris bahwa reputasi penjamin emisi, ukuran penjamin emisi, prosentase penawaran 
saham dan nilai penawaran saham secara signifikan berpengaruh terhadap return 15 hari sesudah IPO. Untuk menguji apakah informasi yang tercantum dalam prospektus berpengaruh terhadap keputusan invesatsi di pasar saham sekunder, hipotesis 2 dirumuskan sebagai berikut:

$\mathrm{H}_{01}$ : Reputasi auditor, reputasi penjamin emisi, umur perusahaan, prosentase saham yang ditawarkan, waktu listing. profitabilitas, solvabilitas, Financial leverage dan standar diviasi return perusahaan tidak berpengaruh secara signifikan terhadap return 15 hari setelah IPO.

$\mathrm{H}_{\mathrm{A1}}$ : Reputasi auditor, reputasi penjamin emisi, umur perusahaan, prosentase saham yang ditawarkan, waktu listing. profitabilitas, solvabilitas, Financial leverage dan standar diviasi return perusahaan berpengaruh secara signifikan terhadap return 15 hari setelah IPO.

\section{METODE PENELITIAN}

\section{Sampel dan Sumber Data}

Populasi dalam penelitian ini didifinisikan sebagai perusahaan yang go public yang tercatat di Bursa Efek Jakarta yang melakukan penawaran saham perdana, IPO. Sementara sampelnya adalah perusahaan yang melakukan IPO periode tahun 1994 sampai pertengahan 1999. Pemilihan periode tersebut didasarkan pada pertimbangan praktis, yaitu ketersediaan data mengenai harga saham saat dan setelah IPO, dan prospektus perusahaan tersedia di pojok BEJ MM UII. Di samping itu hanya observasi yang memiliki underpriced (initial return positif) yang dijadikan sampel ${ }^{1}$.

Data tentang perusahaan yang melakukan IPO berasal dari Directory of Capital Market. Sementara data mengenai harga saham didapatkan dari ICMD CD ROM. Lalu data mengenai ranking penjamin emisi diperoleh dari majalah Uang dan Efek.

\section{Variabel Penelitian dan Pengukurannya}

Difinisi dan pengukuran variabel-variabel yang digunakan dalam penelitian diuraikan sebagai berikut.

\section{Initial return (LnIri)}

Initial return didifinisikan sebagai selisih antara harga penawaran umum (offering price) dengan harga penutupan di pasar sekunder pada hari pertama (closing price). Dengan demikian initial return dihitung dengan rumus sebagai berikut (Firth and Smith, 1992 ; dan Trisnawati, 1999):

\section{(Initial market price - Issue Price) $100 \%$}

\section{Issue Price} 1 Dengan persyaratan tersebut, penginterprestasian hasil penelitian ini harus dilakukan secara hati-
hati. 


\section{Return 15 hari sesudah IPO (Iri15)}

Return 15 hari sesudah IPO didifinisikan sebagai rata-rata return (mean adjusted return) harian saham selama 15 hari saham tersebut diperdagangkan di pasar sekunder (Christy et. al., 1996; dan Trisnawati, 1999). Return harian dihitung dengan persamaan berikut ini:

\section{(Harga saham ${ }_{t+1}-$ Harga saham $_{t}$ ) $100 \%$}

$$
\text { Harga saham } t_{t}
$$

\section{Reputasi auditor (AUDT)}

Reputasi auditor menunjukkan kualitas dan profesionalisme auditor yang mengaudit laporan keuangan perusahaan. Raputasi auditor didasarkan pada frekwensi penugasan yang dilakukan oleh emiten. Perusahaan yang menggunakan auditor yang berkualitas tinggi dapat diartikan sebagai sinyal kualitas emiten (Daljono, 2000). Dalam penelitian ini, auditor yang menempati urutan satu sampai empat akan menjadi auditor yang prestisius (Trisnawati, 1999; Daljono, 2000; dan Nasirwan 2000). Dan yang lainnya akan menempati auditor yang non prestisiuos. Reputasi auditor diukur dengan menggunakan dummy variabel, dimana nilai 1 untuk auditor yang prestisius, dan nilai 0 untuk auditor yang tidak prestisius (Sunariyah, 1993; dan Trisnawati, 1999).

\section{Reputasi penjamin emisi (IBANK)}

Reputasi underwriter didifinisikan sebagai skala kualitas underwriter dalam menawarkan saham emiten. Pemeringkatan penjamin emisi didasarkan pada fee yang didapatkan penjamin emisi. Fee penjamin emisi menunjukkan jumlah saham dan banyaknya saham yang dapat dijamin oleh penjamin emisi, secara tidak langsung menunjukkan asset yang dimiliki penjamin emisi (Hidayati dan Indriantoro, 1998). Pengukuran variabel penjamin emisi juga menggunakan variabel dummy, dengan nilai 1 untuk yang reputable dan 0 untuk yang tidak punya reputasi sesuai dengan rangking yang keluarkan oleh majalah Uang dan Efek (Trisnawati, 1999; Daljono, 2000; dan Nasirwan 2000).

\section{Umur perusahaan (LnAGE)}

Umur perusahaan menunjukkan kemampuan perusahaan dapat bertahan hidup dan banyaknya informasi yang bisa diserap oleh publik. Semakin lama umur perusahaan semakin banyak informasi yang bisa diserap masyarakat (Daljono, 2000). Dalam penelitian ini, variabel umur dihitung sejak perusahaan didirikan sampai penawaran perdana dilakukan (Christy et.al.1996; Trisnawati, 1999; Daljono, 2000; dan Nasinwan 2000).

\section{Prosentase penawaran (OFFER)}

Besarnya prosentase penawaran saham didifinisikan sebagai perbandingan antara jumlah saham yang dijual kepada masyarakat pada saat IPO dengan total saham beredar (Trisnawati, 1999; Daljono, 2000; dan Nasirwan 2000). Formula yang digunakan untuk mengukur prosentase penawaran adalah : 
(Jumlah saham beredar - Jumlah saham yang dijual ke publik) $100 \%$ Jumlah saham beredar

\section{Profitabilitas perusahaan (ROA)}

Profitabilitas didifinisikan sebagai kemampuan perusahaan untuk mendapatkan keuntungan operasi. Penelitian ini menggunakan return on asset (ROA) sebagai pengukur tingkat keuntungan perusahaan. Pengukuran tersebut mengikuti teknik yang digunakan oleh Kim et. al. (1993); Trisnawati (1999) dan Daljono (2000).

\section{Financial leverage (LEV)}

Financial leverage didifinisikan sebagai kemampuan perusahaan dalam melunasi semua kewajiban dengan equitynya. Financial leverage diukur dengan rasio total debt terhadap total equity seperti yang dilakukan oleh Kim et al. (1993) dan Trisnawati (1999).

\section{Solvabilitas perusahaan (SOLV)}

Solvabilitas perusahaan didifinisikan sebagai kemampuan perusahaan dalam melunsai semua kewajiban dengan asset yang dimilikinya dan diukur dengan membandingkan total hutang terhadap total asset (Trisnawati, 1999; dan Daljono, 2000).

\section{Periode penawaran (PERIOD)}

Periode penawaran didifinisikan sebagai waktu listing yang dilakukan oleh perusahaan. Dummy variabel bernilai 0 diberikan bila IPO dilakukan sebelum krisis ekonomi (sebelum pertengahan 1997), sebaliknya bernilai 1 bila terjadi selama krisis. 1 Juni 1997 dijadikan sebagai pisah batas (cut off) terjadinya krisis ekonomi karena semenjak periode tersebut terjadi pergantian pemerintahan yang ditandai dengan penurunan nilai tukar rupiah secara drastis. Variabel kontrol ini sebelumnya digunakan oleh Philip et. al. (1995) tapi belum pernah digunakan pada penelitian di Indonesia.

\section{Standar diviasi return saham (STD)}

Standar diviasi didifinisikan sebagai sebagai penyimpangan nilai return harian selama 15 hari sesudah IPO. Variabel ini digunakan mengukur ketidakpastian (uncertainty) IPO. STD dihitung dari rata-rata return harian selama 15 hari diperdagangkan di pasar sekunder (Guiness, 1988).

\section{Model yang digunakan}

Untuk menguji hipotesis yang diajukan model regresi berganda akan dipergunakan dengan formula sebagai berikut.

Hipotesis 1:

$$
\begin{aligned}
\text { LnIR }_{i t}=\alpha+ & \beta_{1} \text { AUDT }_{i}+\beta_{2} \text { IBANK }_{i}+\beta_{3} \text { LnAGE }_{i . t} \\
& +\beta_{4} \text { OFFER }_{i}+\beta_{5} \text { ROA }_{i}+\beta_{6} \text { LEV }_{i}+\beta_{1} \text { SOLV }_{i} \\
& +\beta_{8} \text { PERIOD }_{i}+\beta_{9} \text { STD }+e_{i}
\end{aligned}
$$


Hipotesis 2:

$$
\begin{aligned}
\text { IR }_{i 15}=\alpha+\beta_{1} & \text { AUDT }_{i}+\beta_{2} \text { IBANK }_{i}+\beta_{3} \text { LnAGE }_{i . t} \\
& +\beta_{4} \text { OFFER }_{i}+\beta_{5} \text { ROA }_{i}+\beta_{6} \text { LEV }_{i}+\beta_{1} \text { SOLV }_{i} \\
& +\beta_{8} \text { PERIODi }_{i}+\beta_{9} \text { STD }_{+}+e_{i i}
\end{aligned}
$$

Di mana:

LnIR $\quad:$ Log initial return

IR $\quad:$ : Initial return 15 hari setelah IPO

AUDT $i \quad$ : Reputasi auditor

IBANK ${ }_{i} \quad$ : Reputasi penjamin emisi

LnAGE $_{i} \quad$ : Log umur perusahaan.

OFFER $_{i} \quad$ : Prosentase penawaran saham saat IPO

$\mathrm{ROA}_{i} \quad$ : Rate of return on asset.

$\mathrm{LEV}_{\mathrm{i}} \quad$ : Financial leverage.

SOLV $_{i} \quad:$ Solvabiltas perusahaan

Period $_{i} \quad$ : Periode menawarkan saham.

STD : Standar diviasi return harian.

Dengan persamaan tersebut di atas, suatu variabel independen disimpulkan berpengaruh terhadap dependen variabel bila koefisien $\beta$-nya secara statistik signifikan tidak sama dengan nol $(\beta \neq 0)$.

\section{HASIL DAN DISKUSI PENELITIAN}

\section{Data Deskriptif}

Sampel penelitian ini adalah perusahaan yang IPO sejak tahun 1994 sampai Desember 1999 berdasarkan Directory Capital Market Indonesia 19942000. Emiten yang melakukan IPO pada rentang waktu tersebut berjumlah 131 perusahaan. Dari jumlah itu, 91 perusahaan atau $70 \%$ memiliki return positif (initial return). Jumlah perusahaan yang melakukan IPO dan jumlah sampel yang memenuhi persyaratan selama periode pengamatan ditampilkan pada tabel 2. Table 3 menunjukkan distribusi sampel berdasarkan industri dan tabel 4 merupakan ringkasan statistik diskriptif masing-masing data variabel penelitian.

\section{Pengujian Hipotesis 1}

Pengujian hipotesis dilakukan dengan meregresi variabel reputasi auditor, reputasi penjamin emisi, umur perusahaan, ROA, solvabilitas, financial leverage, dan standar diviasi terhadap initial return seperti pada persamaan 1. Hasil regresi persamaan 1 tampak pada tabel 5 .

Tabel 5 menunjukkan bahwa variabel prosentase penawaran secara signifikan berpengaruh terhadap initial return. Pengaruh tersebut dapat ditunjukan dengan besarnya p-value yang lebih kecil dari $10 \%$. Hasil ini gagal mendukung hasil penelitian yang dilakukan di Indonesia oleh (Trisnawati, 1998; Nurhidayati \& Indriantoro, 1998; Daljono, 2000; dan Nasirwan, 2000), 
tapi memperkuat hasil penelitian yang dilakuan oleh Beatty, 1989; Caster and Dark, 1992; Philip et. al., 1995; dan Michaelly dan Shaw, 1995).

Signifikannya koefisien prosentase penawaran $\left(\beta_{4}\right)$ mungkin menunjukkan adanya informasi private yang dimiliki oleh pemegang saham lama seperti disinyalir oleh Budiarto dan Baridwan (1999). Informasi ini digunakan oleh pemodal sebagai sinyal bahwa prospek perusahaan baik. Dengan kata lain, semakin kecil prosentase saham yang ditawarkan ke publik semakin kecil ketidakpastian perusahaan di masa yang akan datang (Daljono, 2000).

Tabel 2

Perbandingan Jumlah Sampel dan Populasi

\begin{tabular}{|c|c|c|c|}
\hline Tahun & Populasi & Sampel & \% sampel \\
\hline 1999 & 9 & 5 & $56 \%$ \\
\hline 1998 & 6 & 4 & $67 \%$ \\
\hline 1997 & 31 & 25 & $80 \%$ \\
\hline 1996 & 18 & 14 & $78 \%$ \\
\hline 1995 & 20 & 11 & $55 \%$ \\
\hline 1994 & 47 & 32 & $67 \%$ \\
\hline Total & 131 & 91 & $70 \%$ \\
\hline
\end{tabular}

Tabel 3

Distribusi Sampel Berdasarkan Industri

\begin{tabular}{|l|c|r|}
\hline Industri & Jumlah & $\%$ \\
\hline Pertanian & 6 & $6.60 \%$ \\
\hline Pertambangan & 3 & $3.30 \%$ \\
\hline Industri Dasar dan Kimia & 11 & $12.00 \%$ \\
\hline Aneka Industri & 8 & $9.00 \%$ \\
\hline Industri Barang Konsumsi & 9 & $9.90 \%$ \\
\hline Properti dan Real Estate & 14 & $15.00 \%$ \\
\hline Infrastruktur, Utilitas dan Transportasi & 6 & $6.60 \%$ \\
\hline Industri Keuangan & 22 & $24.00 \%$ \\
\hline Perdagangan, Jasa dan Investasi & 11 & $12.00 \%$ \\
\hline Total & 91 & $100.00 \%$ \\
\hline
\end{tabular}


Tabel 4

Statistik Deskriptif Variabel-Variabel Yang Digunakan

\begin{tabular}{|l|r|r|r|r|}
\hline \multicolumn{1}{|c|}{ Variabel } & \multicolumn{1}{c|}{ Mean } & \multicolumn{1}{c|}{ Std. Dev } & \multicolumn{1}{c|}{ Minimum } & Maximum \\
\hline LnAGE & 1.0684 & 0.3494 & 0.0000 & 1.7243 \\
\hline OFFER & 0.2662 & 0.1111 & 0.0219 & 0.6600 \\
\hline ROA & 11.6065 & 17.8465 & 0.0041 & 100.0000 \\
\hline LEV & 5.6610 & 10.7180 & 0.0557 & 72.7754 \\
\hline SOLV & 0.6385 & 0.2598 & 0.0439 & 1.3965 \\
\hline IR15 & 0.0025 & 0.0099 & -0.0191 & 0.0612 \\
\hline STD & 0.0571 & 0.0417 & 0.0039 & 0.2449 \\
\hline LnIR & 0.9667 & 0.5277 & -0.2175 & 2.0177 \\
\hline
\end{tabular}

Tabel 5

Hasil Pengujian Hipotesis 1

\begin{tabular}{|l|c|c|c|}
\hline \multicolumn{1}{|c|}{ Variabel } & $\beta$ & Std. Error & prob-value \\
\hline KONSTANTA & 0.453 & 0.210 & 0.034 \\
\hline AUDT & -0.017 & 0.127 & 0.895 \\
\hline IBANK & 0.076 & 0.089 & 0.400 \\
\hline LnAGE & -0.036 & 0.106 & 0.733 \\
\hline OFFER & 0.565 & 0.339 & 0.099 \\
\hline ROA & 0.003 & 0.003 & 0.246 \\
\hline LEV & -0.001 & 0.004 & 0.699 \\
\hline SOLV & 0.166 & 0.184 & 0.371 \\
\hline PERIOD & 0.280 & 0.119 & 0.021 \\
\hline STD & 8.671 & 0.904 & 0.000 \\
\hline
\end{tabular}

Tabel 5 juga menunjukkan bahwa waktu listing dan standar diviasi return secara signifikan berpengaruh terhadap initial return. Signifikansi koefisien $\beta_{8}$ menunjukkan ketidaksamaan regresi 1 pada periode sebelum dan selama krisis ekonomi di Indonesia, atau dengan kata lain periode penawaran mempengaruhi initial returns. Signifikannya waktu listing konsisten dengan hasil yang diberikan oleh Philip et. al. (1995). Variabel kontrol ini sebelumnya belum pernah digunakan oleh peneliti di Indonesia sebelumnya dan sekaligus memperbaiki kelemahan pada penelitian sebelumnya. Karenanya variabel waktu listing mungkin salah variabel kontrol yang menyebabkan ke tidakkonsistenan hasil penelitian sebelumnya.

Sementara itu, signifikannya koefisien standar diviasi mendukung hasil yang diberikan oleh Guiness (1988), dan Caster dan Dark (1992). Hasil ini bisa dinterpretasikan bahwa ketidak pastian IPO (yang diukur dengan standar diviasi returns setalah 15 hari IPO) ikut berperan dalam menentukan initial returns.

Secara umum hasil pada tabel 5 tersebut berimplikasi, hanya tiga variabel informasi non-akutansi yang bermanfaat dalam pembuatan keputusan 
di pasar modal saham perdana. Informasi yang lain di dalam prospektus terutama informasi akuntansi tidak digunakan oleh pemodal. Hal ini mungkin terjadi karena para investor lebih mengutamakan informasi di luar prospektus atau dapat pula emiten yang melakukan investasi di pasar perdana untuk kegiatan spekulasi untuk mendapatkan initial return.

\section{Pengujian Hipotesis 2}

Pengujian hipotesis dilakukan dengan meregresi variabel reputasi auditor, reputasi penjamin emisi, umur perusahaan, ROA, financial leverage, solvabilitas dan standar diviasi terhadap rata-rata return 15 hari sesudah IPO seperti pada persamaan 2. Hasil regresi persamaan 2 tampak pada tabel 6 berikut ini:

Tabel 6

Hasil Pengujian Hipotesis 2

\begin{tabular}{|l|c|c|c|}
\hline \multicolumn{1}{|c|}{ Variabel } & $\beta$ & Std. Error & p-value \\
\hline KONSTANTA & 0.0015 & 0.005 & 0.781 \\
\hline AUDT & -0.0070 & 0.003 & 0.037 \\
\hline IBANK & 0.0055 & 0.002 & 0.021 \\
\hline LnAGE & -0.0027 & 0.003 & 0.333 \\
\hline OFFER & 0.0140 & 0.009 & 0.116 \\
\hline ROA & -0.0000 & 0.000 & 0.996 \\
\hline LEV & 0.0003 & 0.000 & 0.009 \\
\hline SOLV & 0.0000 & 0.001 & 0.994 \\
\hline PERIOD & 0.0049 & 0.003 & 0.116 \\
\hline STD & 0.0834 & 0.024 & 0.001 \\
\hline
\end{tabular}

Tabel 6 menunjukkan bahwa variabel reputasi auditor secara signifikan mempengaruhi rata-rata return 15 hari sesudah IPO. Signifikansi variabel ini mungkin merupakan sinyal kualitas emiten sebab dengan memakai auditor yang profesional kesempatan emiten menyajikan informasi yang kurang akurat ke pasar menjadi kecil (Daljono, 2000). Hasil ini tidak ditemukan pada penelitian-penelitian yang dilakukan oleh Christy et. al. (1996), Trisnawati (1998), dan Nasirwan (2000).

Underwriter merupakan pihak yang bertanggungjawab terhadap berhasil tidaknya penawaran saham. Bila emiten menggunakan penjamin emisi yang berkualitas tinggi (reputable), para pemodal akan merespon secara positif terhadap informasi tersebut. Sebaliknya para investor akan memberikan sinyal negatif bila emiten menggunakan underwriter yang kurang profesional. Tabel 6 menunjukkan bahwa variabel reputasi penjamin emisi berpengaruh terhadap rata-rata return 15 hari setelah IPO. Koefisien variabel tersebut bertanda positif dan secara statistik signifikan pada alpha 5\%. Hasil ini mendukung hasil yang dikemukakan oleh Nasirwan (2000). Dengan demikian, keberadaan penjamin 
emisi dapat katakan sebagai informasi yang berguna bagi pemodal dalam pembuatan keputusan di pasar saham sekunder.

Financial leverage merupakan ukuran kemampuan perusahaan untuk melunasi kewajiban dengan equitynya. Hasil pada tabel 6 mendukung hasil penelitian yang dilakukan oleh Kim et. al. (1993) dan Trisnawati (1998), yaitu variabel Financial leverage secara signifikan berpengaruh terhadap ratarata retun 15 hari setelah IPO. Hasil tersebut menunjukkan bahwa semakin besar Financial leverage semakin besar juga rata-rata return 15 hari setelah IPO. Karena Financial leverage merupakan ukuran resiko perusahaan, hasil ini juga konsisten teori risk and return yang berasumsi bahwa semakin tinggi resiko suatu perusahaan maka investor menginginkan return yang tinggi bila berinvestasi pada perusahaan tersebut.

Koefisien standar diviasi juga berpengaruh terhadap rata-rata return saham setelah 15 hari IPO. Signifikannya koefisien standar diviasi mendukung hasil yang diberikan oleh Nasirwan (2000). Akan tetapi, hasil ini tidaklah mengagetkan karena standar diviasi dan rata-rata return dihitung dari data pada periode dan perusahaan yang sama.

Secara umum hasil pada tabel 6 tersebut memberikan bukti empiris bahwa empat variabel informasi dari prospektus bermanfaat dalam pembuatan keputusan di pasar modal saham sekunder. Informasi yang lain di dalam prospektus tidak digunakan oleh pemodal. Dengan demikan dapat disimpulakn baik informasi akuntasni dan non-akuntansi digunakan oleh para investor dalam pembuatan keputusan di pasar saham sekunder.

\section{Uji Klasik Persamaan Regresi 1 dan 2}

Uji atas asumsi klasik pada persamaan 1 dan 2 dilakukan untuk mengetahui apakah data yang digunakan layak atau tidak untuk dianalisa. Pengujian meliputi outlier, autokorelasi, multikorelasi dan heterodasitas². Suatu observasi dikatakan outlier bila observasi tersebut memiliki selisih antara nilai prediksi dan sesungguhnya sangat besar. Dari dua persamaan regresi yang digunakan tidak satupun observasi yang dikategorikan sebagai outlier karena semua observasi yang mempunyai nilai Cooks' distance sebesar kurang dari 2,50 (Dilorio, 1991).

Nilai Durbin Watson (DW) digunakan sebagai prosedur formal untuk menguii keberadaan autokorelasi. Menurut Dilorio (1991) nilai DW yang mendekati 2 mengindikasikan tidak terdapat autokorelasi. Hasil tes dari persamaan regresi yang digunakan tidak menunjukkan adanya autokorelasi.

Uji multikolinieritas dilakukan dengan melihat nilai VIF dan nilai tolerancenya. Menurut Judge et. al. (1988) bila nilai VIF salah satu variabel dari suatu persamaan berganda sebesar 10 atau lebih, maka variabel tersebut terinflasi. Karenanya, terdapat multikolinieritas pada persamaan tersebut. Hasil pengujian statistik pada penelitian ini menunjukkan semua indipenden variabel memiliki nilai

2 Kutipan hasil pengujian tes-tes tersebut tidak dilampirkan karena keterbatasan jumlah halaman yang diberikan oleh redaksi. 
VIF dibawah 10 dan nilai tolerance di atas 0,1. Karenanya variabel-variabel pada persamaan 1 dan 2 tidak mengindikasikan adanya multikorelasi.

Salah satu cara yang digunakan untuk mendeteksi adanya heterokedastisitas yaitu dengan menggunakan Spearman correlation coefficient. Bila korelasi antar variabel independen dalam model memiliki nilai residu kurang tidak signifikan pada level 5\% maka terjadi homoskedasitas. Semua koefisien korelasi antar variabel pada penelitian tidak isgnifikan pada level $5 \%$, suatu indikasi tidak adanya masalah heterodisitas.

\section{PENUTUP}

Penelitian ini bertujuan untuk menganalisa apakah informasi prospektus baik informasi akuntansi dan non-akuntansi digunakan para pemodal dalam pembuatan keputusan investasi di pasar saham. Informasi akuntansi yang digunakan adalah ROA, financial leverage, dan debt ratio. Sementara informasi non-akuntansi meliputi reputasi auditor, reputasi penjamin emisi, prosentase penawaran, umur perusahaan, waktu listing dan satandard diviasi return. Keputusan investasi di pasar saham perdana dan sekunder masing-masing diukur dengan initial return positif dan rata-rata return 15 hari setelah IPO.

Hasil penelitian ini menunjukkan bahwa variabel prosentase penawaran, waktu listing dan standar diviasi return secara signifikan berpengaruh terhadap initial return. Implikasinya hanya tiga variabel informasi non-akuntansi tersebut yang bermanfaat dalam pembuatan keputusan di pasar modal saham perdana. Dengan kata lain, hanya informasi non-akuntansi yang bisa dipertimbangkan oleh para pemodal sebelum membuat keputusan investasi di pasar saham perdana.

Hasil penelitian ini juga menunjukkan bahwa variabel reputasi auditor, reputasi penjamin emisi, financial leverage, dan standar diviasi berpengaruh terhadap rata-rata return saham setelah 15 hari IPO. Oleh karenanya baik informasi akuntansi dan non-akuntansi digunakan oleh para investor dalam pembuatan keputusan di pasar saham sekunder. Hasil ini memberikan bukti empiris bahwa informasi prospektus bermanfaat dalam pembuatan keputusan di pasar saham sekunder 15 hari setelah IPO.

Walaupun kesimpulan di atas robust setelah dilakukan uji klasik terhadap persamaan regresi, tetapi ada beberapa kelemahan yang juga merupakan saran untuk penelitian selanjutnya. Pertama, hubungan antara variabel dependen dan independen diasumsikan linear. Peneliti tidak mencoba untuk menguji apakah asumsi tersebut valid atau tidak. Karenanya, penelitian selanjutnya bisa mempertimbangkan penggunaan persamaan regresi non-linear.

Kedua, perangkingan reputasi auditor dan penjamin emisi didasarkan pada perangkingan yang dilakukan pada penelitian-penelitian sebelumnya dan bersifat subyektif. Karenanya perangkingan yang dilakukan oleh pihak yang independen pada penelitian lanjutan mungkin memberikan hasil yang lebih valid.

Ketiga, variabel yang digunakan dalam penelitian ini merupakan proksi terhadap informasi yang berasal prospektus perusahaan. Penelitian selanjutnya bisa memasukan faktor makro ekonomi seperti tingkat bunga, nilai 
tukar mata uang sebagai faktor yang mungkin mempengaruhi keputusan investasi.

Terakhir, rata-rata saham 15 hari setelah IPO digunakan sebagai proksi dari keputusan investasi di pasar modal saham sekunder. Penelitian selanjutnya bisa menggunakan abnormal return dan kumulatifnya sebagai pembanding untuk proksi keputusan invesatsi.

\section{DAFTAR PUSTAKA}

Balvers, R, MCDonald dan R.E. Miller, 1988, "Underpricing of New Issues and the Choice of Auditor as Signal Investment Banker Reputation", Accounting Review 63 (Oktober): pp.602-622.

Baron, D. P, 1982, "A Model of the Demand for Investemnt banking Advising and Distribution Servicesa for New Issues", Journal of Finance, 37: pp. 955-976.

Beatty, R.P., 1989), "Auditor Reputation and the Pricing of Initial public offerings", Accounting Review, Vol LXIV. No. 4: pp. 693-707

Budiarto, Arif dan Zaki Baridwan, 1999, "Pengaruh Pengumuman Right Issue Terhadap Tingkat Keuntungan dan Likuditas Saham di BE J periode 1994-1996", Jurnal Riset dan Akuntansi Indonesia, p. 96.

Carter, R. B. dan S. Manascer,1990, "Initial public offerings and Underwriter Reputation", Journal of Finance, Vol VL: pp.285-311.

Carter, R. B., and F. H. Dark, 1992, "An Empirical Examination of Investment Banker Reputation Measures", The Financial Review Vol 27: pp. 355374.

Carter, R. B., F. H. Dark and A.K.Singh, 1998, "Underwriter Reputation, Initial returns, and the Long-Run Performence of IPO Stocks", The Journal Of Finance, I.(1): pp. 285-311.

Christy, M., I. Hasan and S.D Smith, 1996, "A note on Underwriter Competition and Initial public offering", Journal of Business and Accounting, 23: pp. 905-914.

Daljono, 2000, "Analisa Faktor-Faktor Yang Mempengaruhi Initial return Saham yang Listing Di Bej TH 1990-1997", Simposium Nasional Akuntansi II IAI.

Dilorio, F. C, 1991, "SAS Applications Programing: A Gentle Introduction", Duxbury Press, California.

Firth, M. and a. Smith, 1992, "The Accuracy of Profits Forecasts in Initial public offering Prospectus", Accounting and Business Research, 22 (87): pp. 239-247.

Guinness. Paul Mc, 1992, "An Examination of the Initial public offerings in Hongkong: 1980-1990", Journal of Business Finance and Accounting, 19 (2): pp..165-186.

Hanafi, M dan Suad Husnan, 1991, "Perilaku Harga Saham di pasar Perdana", Usahawan, No 11 (November): pp.12-15.

Hanafi, Mamduh, 1998, "Efisiensi Emisi Saham Baru di Bursa Efek Jakarta 1989-1994", Kelola : pp.88-105 
Husnan, Suad., 1996, "Penjualan Saham BUMN Apakah Terjadi Distribusi Kemakmuran", Kelola, 13 (v): pp .62-74.

Judge, George., et. al., (1988), "Introduction to the Theory and Practice of Econemetrics", New York: John Wiley \& Sons.

Kim, K. B., I. Krisky and J. Lee, 1993, "Motives for Going Public and Underpricing: New Findings from Korea", Journal of Business Finance and Accounting, 20(2): pp. 195-211.

Michaelly, R and W Shaw, 1995, "Does the Choice Auditor Convey Quality an IPO", Financial Management, 24 (4): pp. 15-30.

Nasirwan, SE, M.Si, 2000, Reputasi Penjamin Emisi, Return Awal, Return 15 Hari Sesudah IPO, dan Kinerja Perusahaan Satu Tahun Sesudah IPO di BEJ, Makalah Simposium Nasional Akuntansi III. IAl.

Nurhidayati, S and Nur Indriantoro, 1998, "Analisa Faktor-faktor yang Berpengaruhi Terhadap Tingkat Underpriced pada Penawaran Perdana Bursa Effek Jakarta", Journal Ekonomi dan Bisnis Indonesia, 13 (1): pp.21-30.

Surianti, Meily dan Nur Indrianto, 1999, "Ketepatan Ramalan Laba pada Prospektus Penawaran umum Perdana", Jurnal Bisnis dan Akuntansi.

Philip, L., L.Taylor, and T. Walter, 1995, "Australian Ipo Pricing in the Short and Long Run", Journal of Banking and Finance, 17: pp.1190-1202.

Rock, K, 1986, "Why New Issues Are Underpriced", Journal of Financial Economics, 15: pp.187-212.

Sunariyah, 1993, Informasi Prospektus dan Ketepan Peramalan Laba, Tesis S2, Yogyakart: Program Pasca Sarjana, Universitas Gadjah Madah.

Trisnawati, Rina (1999), Pengaruh Informasi Prospektus pada Return Saham Pasar Perdana, Simposium Nasional Akuntansi II IAI.

Watts, Ross L. dan Jerord I Zimmerman, 1986, "Positive Accounting Theory", Prentice Hall Int, Inc.

Terima kasih kepada anymous reviewer yang banyak memberikan masukan dan saran. 